\title{
Opinion
}

\section{A Rational and Scientific Explanation for Metempsychosis}

\author{
Seun Ayoade* \\ Alumnus College of Medicine University of Ibadan, Nigeria
}

*Corresponding author: Seun Ayoade, Independent Researcher. Alumnus College of Medicine University of Ibadan, Oyo State, Nigeria.

Received Date: March 02, 2020

Published Date: March 17, 2020

\section{Opinion}

Metempsychosis, or the transmigration of souls, better known as reincarnation is the belief that upon death, a human being can return to the world in a new body. This belief is found in many cultures and religions worldwide. It is easy for today's scientist to dismiss the concept of reincarnation as superstition invented by the imaginings of unenlightened and backward people-yet through the ages, tales abound of people insisting they had been to this planet in times past. The famous World War 2 American General George S. Patton (November 11, 1885 - December 21, 1945), to the amusement and embarrassment of some of his fellow officers, repeatedly insisted during the allied campaign in North Africa in the 1940s that he was the reincarnation of a contemporary of the Carthaginian General Hannibal who had lived two millennia earlier! [1,2]. General George Smith Patton would often allegedly give details of ancient battles not recorded in any history books. The infamous African American rebel slave Nat Turner (died 1831) whilst but a little boy, spoke with clear detail about things that had happened on the plantation he lived many years before he had been born-to the amazement of older, adult slaves [3].

Can human memory be inherited? Can a father pass to his son or a mother to her daughter memories of things she saw or did the same way she can pass on facial features or the color of her eyes and hair, or musical talent? Can memory pass from one individual to another without them being related by blood? Human memory is not yet fully understood, but the present consensus is that part of the temporal lobe of the cerebral cortex is responsible. According to conventional medicine, upon death the cells of an individual perish. According to the germ terrain duality theory however the microzymas/cellular dust, including the cerebral dust of the brain survive-with the memory of the deceased presumably intact [4-7].

I postulate and propose that under certain rare conditions, the cerebral dust of people long dead invade the cerebrum of the living-just as how germs invade-giving people snippets of the memories of the deceased.

This is a scientific and rational explanation for "reincarnation".

\section{Acknowledgement}

None.

\section{Conflict of Interest}

No conflict of interest.

\section{References}

1. Patton: Many Lives, Many Battles: General Patton and Reincarnation (9781481257435) by Hollenbach, Karl F.

2. Through A Glass, Darkly by George S. Patton.

3. Page 2 TheConfessions of NatTurner, The Leader OfThe Late Insurrections In Southampton, Va. As fully and voluntarily made toThomas R. Gray, In the prison where he was confined, and acknowledged by him to be such when read before the Court of Southampton; with the certificate, under seal of the Court convened at Jerusalem, Nov. 5, 1831, for his trial. Also, An Authentic Account of the Whole Insurrection, With Lists of the Whites Who were Murdered, and of the Negroes Brought before the Court of Southampton, And There Sentenced, \&C. Baltimore: Published by Thomas R. Gray. Lucas \& Denver, print. 1831.

4. Seun Ayoade (2018) Re-Examining Time and Time Travel in The Light of The Microzymas. Peer Re J Foren \& Gen Sci 2(4).

5. Seun A (2017) The Future of Medicine Lies in Microzyma Research, Not in Stem Cell Research; Flexner the Germ Theory Fiend. J0J Nurse Health Care 5(2): 555658. 
6. Seun Ayoade (2018) A Few More Differences between the Theories Three. ARC Journal of Nursing and Healthcare 4(3): 1-2.
7. Ayoade S (2017) Koch's Postulates and Germ Terrain Dualism; Cellular Dust as Yet Another Term for Microzymas. J Mol Genet Med 11: 297. 